rial reduction can be made in the number of medical officers in India nor, for the present at least, in South Africa, and the medical needs of the proposed big dépôts of the GeneralService Army and of the territorial battalions of the HomeService Army must be met. If the medical and sanitary work of the army abroad and at home is to be properly done, the establishment of the Army Medical Service cannot be reduced.

The Corps is still short of officers and men, and if the recommendations of the various Royal Commissions still possess the value attached to them when they were made the deficiency must be made good. We believe that neither the public nor the medical profession will be satisfied unless the reforms recommended are carried out, and carried out rather more speedily than we believe latterly has been the case. In the past, when the cry of economy has been raised, it has always been the medical service which has been the first to suffer. Already there are signs that it is to suffer now if Mr. Arnold-Forster has his way unchecked; no progress, for instance, has been made with the Royal Army Medical College, the plans for which were, as we announced at the time, sanctioned more than six months ago-the first sod has not yet been turned. When we find that the vital question of national defence is being considered on the basis of making reductions in the future, we feel bound to warn the authorities that such reductions cannot safely be made in the medical branch of the army, and that if they are attempted an appeal must be made to the people of this country to insist on the prompt execution of those measures which the late war showed to be essential for the efficiency of the Army Medical fervices.

ROYAL NAVY MEDICAL BERVICE.

THE following appointments have been made at the Admiralty: HERBERT M. ELIIS, Inspector-General, to the President, for temporary service at the Admiralty, August rst ; HENRY F. ILIEW ICZ, Fleet Surgeon, to the Exceldent for the Colossus while guardship at Cowes, August rst; HARBY V. WeLLS, surgeon, to the Dwarf, on recommissioning. undated ; WrLLIAM J. CoDnINGToN. M.B., Surgeon, to the President, for ihree months' course of hospital study, July 25 th; HoGH P. TU HNBULL, Surgeo

\section{SOME GrIevances.}

A CORRESPONDENT sends us the following brief statement of grievances of the officers of the Royal Navy Medical Service. All have been discussed at length in our columns from time to time (we may refer. for example, to three articles published in the first volu
JOURNAL for this year, pp. $679965, x_{3} 86$ ):

IO Acting Appointments. - In the case of the executive, paymaster, and r. Acting Appointments. - In the case of the executive, paymaster, and
ongineering branches a junior officer appointed temporarily to do the ongineering branches a junior officer appointed temporarily to do the ing "commander, assistant paymasier to paymaster, etc. This entitles them to the pay of the higher rask whilst doing the duty. In the them to the pay of the higher rank whilst doing the duiy. In the medical branch there are yo acting appointments given; a ju

of Cabin Accommodalion according to Rank. - The regulations state that 2. Cabin Accommodalion according to Rank. - The regulations state that
officers shall have cabins allotted to them according to their rank, the officers shall have cabins allotted to them according to their rank, the are all labelled in the dockyard before the ship commissions-"commander," surgeon, paymaster, etc.; and invariably the executive cfficers mander," surgeon, paymaster, etc.; and invariably the executive cfficers
have the better cabins, and usually the medical the worst. There is a regulation which states that cabins are not to be altered after being so regulation which states that cabins are not to be altered after being so
labelled. The first regulation is quire useless. Some time ago, when the pay was increased, a regulation stated that a medical officer should he pay was increased, a regulation stated that a medical officer should officers who have to read and do much work in their cabins should invariably have an upper-deak cabin.

Appointments - Instead of appointments being, as at present, a matter of favouritism, a roster should be kept, and all medical officers go to sea in turn (according to their rank in regard to ships of various sizes). At present there are several junior officers who have hela home tioned.

4. Jurisdiction.-Medical officers should, as in the army sit on courtsmartial of their own men. Medical officers in charge of jarge hospitals -as Haslar, PJymouth, and Chatham-should have ihe powers of a captain in regard to punishments. At present accused and witnesses are sent on board the depot ship or the $R$. N. barracks, where the captain judges the case, probably not understanding it in the least, and therefore giving an inappropriate punishment. In

in sending the people backwards and forwards. cases, and dentistry should be given to each squadron-Mediterranean, China, Australia, etc - officers being given a chance of qualifying for these, and receiving extra pay. At present 1here are no officers in any squadron specially qualified in any of these specialities, It is impossible for every medical oficer to be a spech

the present system he is supposed to he.
Every medical officer should have a three months' course at a London hospital after a commission abroad.

A Correction: In the notice of the appointment of $\mathrm{Mr}$. R. Balfour Graham as Surgeon and Agent at Leven, published last week, page ${ }_{153}$, the initials were incorrectly printed.

\section{ROYAL ARMY MEDICAL CORPB.}

Tre undermentioned Lieutenants to be Captains, dated June 27th: F. W. J ambelle, M.B., M. C. Beatty, M.B., T. F. Ritchie, M.B., A. W. Bampey. T.
J. Potter, A. J. Williamson, M. B., E. V. Aylen, H. Rogers, M.B , W. Davis,
D. J. F. O'Donoghue. Their first commissions are dated June 27 th, rgor. Captain Beatty was in the South African war in rgor (Queen's medal with four clasps) ; Captain Ritchie, Bouth African war rgor-2, inclnding operations in the Transvaal and Orange River and Cape Colopies (mentioned in dispatches); Captain Williamson. South African war, 1901-2 (King's in the Army List.

The undermentioned Lieutenants are confirmed in that rank: R. M. Ranking, F. J. Turner, G. F. Rugg, D. S. B. Thomson, M. B., J. Fairbairn, M.B., L. Bousfeld, M.B., J. H. Douglass, M.D., A. S Arthur, M.B., R. R. Lewis, A. L. Otway, M.B. C. H. Turner, D. Le Bas, E. C. Whitehead, M.B.,
W. F. H. Vaughan, R. B. Hole, M B., T. C. Lncas, G. E. Cathcart, W. Wiley, M.B. H. Harding, M.B., J. A. Turnbuli, M. F. Grant, D. P. Johnstone, E. H. M. Moore, M. B. Ahern, F. J. Garland, M. B. A. A. Meaden, R. J. Cahill
M.B., H. B. Connell. Of these officers Lieutenant Ranking was appointed on probation Jannary 3ist, ro03; Lieutenant Turner, August 31st, I903; and all the others, January, ro03; Lith

Capcain HENRY EverED HAYMEs died at Tong, Upper Egypt, on Captain HENRY EvereD HAYMEs died at Tong, Upper Egypt, on
March isth last. He was appointed Lieutenant, January 23th, ic99, and Captain, January 28th, rgo2. He was attached to the Egyptian army, September 27th, 1899 .

\section{Changes of station.}

THz following changes of station amongst the officers of the Royal Army Medical Corps have been officially reported to have taken place during the last month :

Colonel W. E. Saunders, C.B. F. W. Trevor, M.B.

" G. A. Hughes, M.B.... T. B. Emerson T. P. MacNeece. O'Connor, C. B. W. Dugdale A. O. Geoghegan, M.̈. J. H. A. Rhodes

Major W. C. Beevor, M.B., C.M.G...

J. R. Mallins, $M$.

C. L. Josting

J. M. Nicolls, M.B

R. W. Wright

J. W. Bullen, M. . D.

J. W. Jennings, D S.O

Captain A. F. Tyrreli

H. W. H. O'Reilly, M̈.B

L. Addams-Williım $\begin{array}{cccccc}\text { H. S. Taylor } \ldots \ddot{m} & \ldots & \ldots & \ldots & \text { Woolwich } & \text { W. Afric } \\ \text { Lieütenant T. J. Wright. } & \ldots & \ldots & \ldots & \text { Dublin. }\end{array}$

From. To. Poona ........ Meerut. Scottish Dist.... Poona. Publin ... $\ldots$... Scoit Portsmouth ... York. Gibraltar: Netley Chester Bord on. S. Africa. Birmingham ... Bury. Scots ̈̈uards... Home District. Halifax, N.S.... Portsmouth. Hong Kong. Butterant $\begin{array}{lll}\text { Chester } & \ldots & \text { Birmingham. } \\ \text { Bengal ... } & \ldots & \text { Portsmouth. }\end{array}$ Abyssinia Chester. Dublin... ... $\quad$ S. Africa. Limerick ... S. Africa. Bristol .. W. Africa. Surgeon-Lieutenant-Colowel G. S. Robinson and Major P. Connolly retired pay, have been placed in medical charge of troops at Beliast and Eastbourne respectively.

The undermentioned Lieutenant-Colonels on retired pay have relinquished the medical charge of troops at the stations cited: J. E. Fannin,
Eastbourne; J. O'Reilly, M.B., Guildford; E. A. H. Roe, M B., Belfast; Eastbourne ; J. O'Reilly, M.
J. E. Nicholson, Fleetwood.

\section{Examination of Ma.jors for Promotion.}

AN Army Order just issued announces that for the year 1005 the specia subjects for the examination of majors, Royal Army Medical Corps, for promotion to the rank of lieutenant-colonel, referred to in paragraph 5 $(a)$, (b), and (c), Appendix VIII B, of the King's Regulations (inserted by Army Order 182 of 1903 ) will be:-Subject 5 (a): Medical history of more important campaigns. The medical history of expeditions in the Soudan and Nile Valley, as described in Army Medical Department Reports. vol. xxiv, r882, Appendix I : vol. XXv, r883. Appendix VII ; and rol. Xxvi. 1884, Appendices I, II, III, and IV. Subject $5($ b): A general knowledge of the Army Medical Services of other Powers. The medical organization of the Russian army as described in tbe Handbook of Medical Organization of Foreign Armies. and in Army. Medical Department Report for 1889, Part III of Appendix IV: or the medical organization of a foreign army, selected by the candidate, described within similar limits. examined in this subject.

\section{KING EDWARD VII.'S HOSPITAL FOR OFFICERS.}

THE following list of the Honorary Medical Staff for King Edward VII's Hospital for Ôfficers, 9, Grosvenor Gardens, S.W., appointed hy His Royal Highness the Prince of Wales, President. and His Royal Highness the Duke of Connaught, Vice-President, of the Hospital, the appointment being for five years from January rst, r904, has been approved by $\mathrm{H}$ is Majesty as Patron:

Consulting Surgeons: Sir Thomas Smith, Bart, K.C.V.O, F.R.C.s., Sir rederick Treves, Bart., K.C.V.O., C.B., IL.D., F.R.C.s.

Medical Ofticer: Dr. Charles A. Morris, C.V.O., M.A., M.C., F.R.C.S. Si Thomas Barlow, Bart., K.C.V.O., Z.D. Li.D., D.Sc., F.R.C.P., Sir Willian Henry Bennett, K.C.V.O., F R.C.S., Mr. Tom Bird. M.A.. M.R.C.8., Mr. Anthony A. Bowlby, C.M.G., F.R.C.s, Sir William Arthur H. Cheatle, F.R.C.S. Mr. G. ienthal Cheatle, C.B., F.M.C.s. Sir Anderson Critchett, F.R.C.S.Edin.. Dr. Alexander Cromhie, C.B., Dr David Ferrier, LL.D., F R.C.P., F.R.S., Mr. P. J. Freyer. M.A. M.D. M.Ch., Sir Alfred D.' Fripp, C.V.O. C.B., M.S., F.R.C.S.. Mr. Rickman Dr. Frederic William Hewitt, M.V.O., M A. Sir Victor A. H. Horsley, B.S F.R.C.S.. F.R.S., Mr. George Henry Makins, C.B., F.R.C.S.. Mr. Percy Lockhart Mummery, M.B., B.C., F.K.C.S., Dr. Frederick W. Pavy, LL.D., F.R.C.P., F.R.S. Sir Richard Douglas Powell, Bart.. K.C.V.O.. M.D.
F.R.C.P., Dr. William Aldren Turner F.R.C.P., Mr. Henry Roe Walker,
M.R.C.S., L.R.C.P.. Dr. William Hale While, F.R.C.P.

Mr. Arihur Blomfield, M.A., F.R.I.B.A., has been appointed architect.

$$
\text { ARMY } \triangle \text { EDICAC DEPARTMENT. }
$$

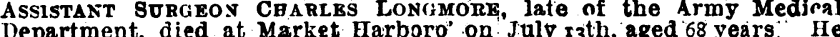

